\title{
THE POLLUTANT EFFECTS OF COPPER, ZINC AND LEAD ON THE HISTOLOGICAL PATTERNS OF FISH KIDNEY
}

\author{
Al-Zahaby, A.S.;Hemmaid, K.Z.; Gamal, A.M. and Ghonemy, 0.I. \\ Faculty of Science, Zagazig Univ.
}

KEY WORDS: Pollutant effect, histopathological changes, Fish, kind ey, $\mathrm{Zn}$, $\mathrm{Pb}, \mathrm{Cu}$.

(Received April 25, 1998)

\section{ABSTRACT}

$\Gamma^{h}$ he present study displayed the histopathological alterations produced In kidneys of Sarotherodon galilaeus fish following exposure to gradually ascending sublethal concentrations of $1 / 4,1 / 2, L C_{50}$ and double $L_{50}$ for 5 days each.

Kidneys from fish exposed to the low levels of mel ats showed slight changes in the proximal convoluted tubular epithelium which were slightly vaculated and the nuclei of its cells were karyorhectic. Hypertrophy, cloudy swelling and hydropic degeneration of some renal tubules as well as congestion of kidney blood vessels were common among fishes exposed to the medium levels of mat els $\left(1 / 2 L_{50}\right)$. Atrophied cellular components of the Bowman's capsules and enlarged Bowman's spaces were also observed in such treated fishes.

In the fish groups exposed to the highest concentrations of zinc and lead, degenerations in the cytoplasm of tubular epithelial cells were so drastic to the extent that the tubules as a whole appeared as if they were ghosts of tubules.

The haemopoietic tissue was reduced in volume in fishes exposed to the $\mathrm{LC}_{50}$ of copper. It was crowded with necrotic cells in case of fishes exposed to the $\mathrm{LC}_{50}$ of lead. The above histological alterations are sufficient to cause 
nephrotoxicity that may lead to impairment in the excretory function of the kidney.

\section{INTRODUCTION}

Pollution of the aquatic environment by heavy mel ats from industrial discharges causes hazards to the living animals including fishes. Bryan (1971) r eported that additional quantities introduced from industrial wastes or sewage, destroy the biogeochemical cycle.

Little work has been done on the toxicological effects of some heavy met als to the kidney of fish (Wobeser, 1975; Sipple et al., 1983; Kirubagaran and Joy, 1988 and Wester and Canton, 1988). Early in 1959, Vogel showed that gold fish treated with $100 \mathrm{mg} / \mathrm{l}$ of copper subjected to severe nephrotoxic and neurotoxic effects. Meanwhile, Baker (1969) reporteda that kidney of winter flounder subjected to considerable pathological changes.

Effects of other heavy mat els, such as cadmium (Gardner and Yevich, 1970) and mercury (Wobeser, 1975 and Wester \& Canton, 1988), on kidney of fishes had been studied.

Recently, Leino et al. (1990) studied the multiple effects of aluminum and acid on the histology of the kidney of brook trout and fat-head minnows. Moreover, hyaline degenerations in kidney tubules were detected in some fish species following toxic additions of mercury (Trump et al., 1975) and exposure to sublethal levels of lead (Sipple et al., 1983). Also, Hemelraad et al. (1990) detected changes in the ultrastructure of kidney mitochondria of Anodonta cygnea following exposure to heavy met als (cadmium). Likewise, glrahim et al. (1997) demonstrated accumulation of heavy met als in tissues of clams.

Other investigators reported that environmental stress resulted in variable histological responses in kidneys of fishes (Hendricks, 1971; Stevens and Bick, 1975; Colville et al., 1983, and Hwang and Wu, 1988). 
Nowadays, large number of factories and industrial companies are established near rives and on sides of their tributaries. Effluents, of a considerable bulk, of such projects are poured in these fresh water currents. Therefore, the present investigation was planned to detect and compare the deleterious changes that may be occurred in the kidney of one of the freshwater tilapian fish Sarotherodon galilaeus under the effect of different concentrations of either copper, zinc or lead. These heavy mat els were proved to be of toxic form (Portmann, 1970).

\section{MATERIALS AND METHODS}

Sarotherodon galilaeus of about $15 \pm 1 \mathrm{~cm}$ total length and $130 \pm 10 \mathrm{gm}$ total weight from both sexes were collected from El-Abassa fish Farm at Sharkia Province. Fishes were maintained in 13 aquaria (10 fish in each) and supplied with continuously aerated fresh water and supplementary food for two weeks in order to acclimatize with laboratry conditions.

Following atomic absorption analysis of water from Nile river near the effluents of factories at industrial areas from three localities (Benha, Helwan and Kafr El-Ziat) the concentrations of copper, zinc and lead were estimated. These concentrations were found to be $6.25,7.5$ and $0.25 \mathrm{mg} / \mathrm{L}$ in average, for the three metals, respectively. Starting from these values, gradual increasing series of copper sulphate, zinc sulphate and lead nitrates were applied to calculate the $96 \mathrm{hrs}-\mathrm{LC}_{50}$. The half lethal concentration $\left(L C_{50}\right)$ for each mat ael was calculated by graphical straight line interpolation, plotted on a semilog paper (Litchfield and Willcoxon, 1949). The $96 \mathrm{hrs}-\mathrm{LC}_{50} \mathrm{~s}$ were found to be 27, 28 and $0.92 \mathrm{mg} / 1$ for copper, zinc and lead, respectivcly.

The first aquarium contained fishes living in non treated fresh water and considered as controls. Fishes of other twelve aquaria were exposed for 5 days to either $1 / 1,1 / 2, L C_{50}$ or double the $\mathrm{LC}_{50}$ of copper, zinc and lead. The $\mathrm{pH}$ value in order to be adjusted between each aquarium was measured twice/day 7.6-8.4. 
Slices from the Kidneys in each case were rapidly fixed in Bouin's fluid, dehydrated, cleared and then infiltrated with paraffin. Sections ( 6 microns) were stained by Haematoxylin and eosin (Harris, 1900).

\section{RESULTS}

The kidneys of $S$ galilaeus are similar in the two sexes. They are not very definite structures but greatly resemble those found in all teleostean fish. The kidneys of $S$. galilaeus are of the mesonephric type. They occur as two elongated brown bodies in the dorsal surface of the body wall above the swim bladder, one on each side of the vertebral column.

\section{Normal histology of fish kidney}

The kidney of Sarotherodon galilaeus is a compound tubular organ composed of huge number of renal units (nephron). Each one consists of Malpighian corpuscle, proximal, distal and collecting tubules. Inbetween these tubules, there is a haemopoietic tissue forming a connecting matrix. However, Malpighian corpuscle is composed of a well vascularized glomerulus inside the Bowman's capsule. The latter is formed of squamous epithelial cells. Between the glomerulus and the Bowman's capsule, there is a space which called the Bowman's space. The renal (Malpighian) corpuscle leads to the proximal segment through a short neck segment. The proximal convoluted tubules are lined with large cuboidal epithelial cells with a conspicuous eosinophilic brush border. The cytoplasm of these cells is eosinophilic, while their nuclei were basophilic, large, oval and centrally located. Each nucleus possessed a prominent basophilic nucleolus (P1. I., Fig.1).

The collecting tubules are lined with cuboidal cells which are slightly eosinophilic and have spherical nuclei with prominent nucleolus. The lumen of these tubules is wider than that of the proximal and distal ones.

The haemopoietic tissue, located inbetween the renal tubules, is composed of polygonal slightly basophilic cells with spherical nuclei. Few scattered blood corpuscles are seen in this haemopoietic tissue (P1. I., Fig.1). 


\section{Histopthological changes \\ 1- Effect of Copper \\ $1 / 4 \mathrm{LC}_{50}$ of Copper}

In fish exposed to $6.75 \mathrm{mg} / \mathrm{L} \mathrm{C \textrm {Cu } ^ { 2 + }}\left(1 / 4 \mathrm{LC}_{50}\right)$, the renal tissues were slightly altered. The most obvious histopathologic response recorded was hydropic degeneration of cells of some proximal and distal convoluted as well as tubule The glomerul were crowded with strongly basophilic nuclei (P1. I, Fig 2).

\section{$1 / 2 \mathrm{LC}_{50}$ of Copper}

The kidney from fish lived in the aquaria containing $13.5 \mathrm{mg} / \mathrm{l} \mathrm{Cu}{ }^{2+}$ showed many histopathological changes which were mainly inflammatory signs. Large spaces were seen around the glomeruli which were atrophied, while the haemopoietic tissue was crowded with infiltrated cells. Cells of some tubules were suffering from more degenerations, and the brush borders of most proximal tubules became shorter (P1. I, Fig. 3).

\section{$\mathrm{LC}_{50}$ of Copper}

A more progressive picture of the forementioned lesions in the previous concentration was detected in the kidney of fish ( $S$. galilaeus) from aquaria containing the sublethal concentration $\left(27 \mathrm{mg} / \mathrm{l} \mathrm{Cu}^{2+}\right)$. Different inflammatory were seen in the renal tubular epithelium including hypertrophy and hydropic degeneration of the renal tubules as well as congestion of the renal blood vessels. Cells of the proximal and distal tubules were enlarged and revealing prominent hydropic degeneration, their nuclei were also hypertrophied and appeared more elongated (P1. I, Fig.4).

\section{Double the $\mathrm{LS}_{50}$ of Copper}

Fish subjected to $54 \mathrm{mg} / \mathrm{l} \mathrm{Cu}^{2+}$ showing with advanced signs of degeneration in its renal segments. Degenerations in the cells of the distal and 
collecting tubules were clear and started near the bases. In the proximal tubules as a whole seemed as if it was a ghost of tubule. The haemopoietic tissue was greatly altered with their cells accumulated and clumped together (P1. I, Fig. 5).

\section{2- Effect of Zinc \\ $1 / 4 \mathrm{LC}_{50}$ of $\mathrm{Zinc}$}

The fish exposed to $7 \mathrm{mg} / \mathrm{l} \mathrm{Zn}^{2+}$ showing kidneys with a rather normal appearance. No clear histopathlogical changes were observed in the nephron constituents (renal corpuscles, neck segment, proximal segment, distal segment and the collecting duct system) (P1. II, Fig. 6).

\section{$1 / 2 \mathrm{LC}_{50}$ of Zinc}

Kidneys from fish held in aquaria containing $14 \mathrm{mg} / 1 \mathrm{Zn}^{2+}$ showed widened Bowman's space and shrinkage of the glomerular tuft of blood capillaries cells were slightly enlarged. On the other hand, the distal convoluted tubules had a wider lumen than control. The nuclei of the cells lining the proximal and the distal tubules showed normal appearance and had a prominent nucleolus. However, in some renal tubules, there was a hydropic degeneration which we more apparent in the proximal ones (P1. II, Fig.7).

\section{$\mathrm{LC}_{50}$ of Zinc}

Fish in this group were subjected to $28 \mathrm{mg} / 1 \mathrm{Zn}^{2+}$ (5-days $\mathrm{LC}_{50}$ ). The proximal tubules showed hydropic degeneration in the whole cytoplasm of their lining cells and it was advanced in their upper regions. On the other hand, degeneration in the distal convoluted tubules was observed at the basal regions of their lining cells. Nuclei of the altered cells were also suffered from pyknosis and some others were karyorrhectic. The haemopoietic tissue in most regions showed an abnormal appearance, where aggregated clumps of cells as well as blood corpuscles with deeply basophilic, pyknotic were also seen on a diffusely reddish ground matrix (P1. II, Fig .8). 


\section{Double the $\mathrm{LC}_{50}$ of Zinc}

The fish exposed to the highest levels of zinc $\left(56 \mathrm{mg} / \mathrm{Zn}^{2+}\right)$ showed kidneys with severe signs of degenerations in the nephron segments. The nuclei of the glomerular cells were pyknotic, coalesced together and deeply basophilic, while Bowman's space was relatively enlarged. Outside the Bowman's capsules, eosinophilic blood were infiltrated. Extraglomerular amyloid degeneration was also observed.

The proximal tubules showed severe hydropic degenerations and fatty changes, whereas the nuclei were karyorhectic in some cells while other cells revealed nuclear karyolysis. At the same time, the brush border of these tubules as well as the basal laminae were intact and strongly eosinophilic. In fact, the proximal tubules with these pathologic alterations appeared as ghosts of tubules.

The distal convoluted tubules were clearly suffered from degenerations in the basal regions of their lining cells. Nuclei of the latter cells were obviously pyknotic. The spaces occupied by the haemopoietic tissue were greatly restricted due to the dilation of the nephritic tubules. Cells of the haemopoietic tissue were necrotic with pyknotic nuclei (P1. II, Fig.9).

\section{3- Effect of Lead}

$1 / 4 \mathrm{LC}_{50}$ of Lead

The fish exposed to $0.23 \mathrm{mg} / 1 \mathrm{~Pb}^{2+}$ showed mild changes in the kidney. Occasionally, the glomeruli were normal were confined to the proximal convoluted tubules. These tubules were slightly vaculated and some nuclei of their lining epithelia were enlarged in size and showed karyorhexis. Other tubules were less affected and revealed slight pathologic alterations. The cytoplasm, of the epithelial cells of the renal tubules was slightly eosinophilic, while their nuclei were deeply basophilic (P1. III, Fig. 10). 


\section{$1 / 2 L C_{50}$ of Lead}

Pathologic alterations in the kidneys of fish inhibated aquarium of 0.46 $\mathrm{mg} / 1 \mathrm{~Pb}^{2+}\left(1 / 2 \quad \mathrm{LC}_{50}\right)$ were more drastic, Degenerations were pronounced specially at the basis of the cells lining the distal segments and tips of that lining the proximal tubules. Nuclei of the epithelial cells in both types of tubules were prevailing different degrees of pyknosis. Cells of the haemopoietic tissue were exhibiting necrotic changes and their nuclei were accumulated together and coalesced in addition to their pyknotic appearance (P1. Ill, Fig. 11).

\section{The $\mathrm{LC}_{50}$ of Lead}

The kidney of the fish subjected to $0.92 \mathrm{mg} / \mathrm{Pb}^{2+}$ (5-days $\mathrm{LC}_{50}$ ) showed advanced alterations represented by higher degenerative changes in their proximal tubules. Also, the degeneration at the basal areas of the cells lining the distal tubules were more severe than those observed in the previous case. In addition, the haemopoietic tissue was necrotic and reduced in volume, while the nuclei of its cells were clearly pyknotic (P1. III, Fig. 12).

\section{Double the $\mathrm{LC}_{50}$ of Lead}

The kidney from fish of this group which exposed to $1.84 \mathrm{mg} /\left[\mathrm{Pb}^{2+}\right.$ (double the $\mathbf{L C}_{50}$ ) showed many signs of degeneration which was more severe and reached the highest level of deformation. The outlines of the epithelial cells of both proximal and distal tubules were disappeared, and the cytoplasmic degeneration in some cells was complete. However, in such cells the nuclei, in spite of their pronounced pyknosis, still present and persisted karyolysis. The nephric tubules consequently lost their constituent feature and looked as if they were ghosts of tubules. The different renal segments compressed the haemopoietic tissue which was reduced in volume (P1. III, Fig.13).

\section{DISCUSSION}

The kidney of teleost fishes is a compound tubular organ with a massive highly vascular structure containing vast numbers of convoluted tubules 

fish kidney

separated from one another by haemopoietic, reticulo-endothelial and internal cells ( Hickman and Trump, 1969; Ali, 1978; Beder, 1983; Al-Zahaby et al., $1985 \mathrm{a \& b}$ and Ghonemy, 1986).

As regards to the histological structure of the tilapian kidney, in all teleost fish, it was formed mainly of renal units or nephrons, which in turn consisted of Malpighian corpuscle comprised a well vascularized glomeruli, short ciliated neck segment, proximal convoluted tubule with brush borders, an intermediate segment, distal convoluted tubule and collecting duct system.

The neck segment is lined by cuboidal cells possessing cilia, while the proximal convoluted tubules are lined by pyramidal cells with narrow lumen and have brush borders. However the distal convoluted tubules are lined with short columnar cells without brush borders, while the collecting tubules are lined with large cuboidal epithelial cells, possessed a wider lamina. These epithelial cells have a basally located nuclei with prominent nucleoli. These results had been observed also by Beder (1983) in Clarias lazera, Al- Zahaby et al. (1985a) in Cyprinus carpio and Ghonemy (1986) in Tilapia nilotica. In between the renal units, an internal tissues formed of polygonal cells and haemopoietic tissues can also be seen. The haemopoietic tissues formed a support matrix for the nephrons of the posterior kidney (Hickman and Trump, 1969).

In the present investigation, Sarotherodon galilaeus showed several histopathological alterations, that were related to the exposure to different levels of heavy met als. Accumulation of heavy mat els in kidneys may be an important factor in their injury. However, accumulation patterns of heavy mat els are dependent on both uptake a:xd elimination rates (Gomaa et al. ,1995). These met als; copper, zinc, and lead; made differences in the ionic composition of their environment. The most significant changes observed in the kidney were glomerular and renal tubules swelling, hydropic and vacuolar degeneration of the tubular epithelium and congestion of the kidney blood vessels, as well as the presence of pigment granules inbetween the renal tubules and nearest the renal. 
corpuscles. The above alterations which were confined to the trunk kidney, are sufficient to cause nephrotoxicity

Kidney, from fish exposed to copper and zinc, showed slight swelling of the epithelial cells lining the proximal convoluted tubule as well as that lining Bowman's capsule. Similar results were observed in the kidney of rainbow trout exposed to methyl mercury (Wobeser, 1975). Newborn guppies exposed for a long period to zinc revealed distended tubules and glomeruli and then kidney tubules were expanded (Grandall and Goodnight, 1963). Swelling and hypertrophy of the proximal convoluted tubules epithelium was also., the histopathologic alterations detected in the kidneys of the rats under the effects of industrial solvent (trichloroethylene) and, in general, stress factors (Rashwan et al., 1988 and Khater et al., 1991). According to Abd-El-Dayem (1990), the swelling of the epithelial cells of proximal convoluted following treatment with benzyl alcohol could be an indication of regenerative changes in these tubules. Swollen cells of proximal and distal convoluted tubules have either obliterated lumena or contain debris of tissues (Adieb et al., 1986).

Amyloid degeneration in kidney tubules was reported in fish subjected to zinc. Nearly similar finding had also been reported in fish following toxic additions of mercury (Trump, et al., 1975), the rodenticide,Warfarin (Fernandez, 1977), and sublethal levels of lead (Sippel et al., 1983).

Moreover, cloudy swelling was a pathologic alteration observed in the epithelial cells lining the nephric tubules, especially the proximals, proceeding hydropic degeneration in copper or zinc toxicity groups.

It seemed likely that cloudy swelling is a common pathologic alteration displayed by the kidneys affected by various substances. It was also described in renal tubules of rats following caffeine or phenacetin (drug) administration (Tadros et al. 1985 and Tadros \& Mohamed, 1990), respectively, as well as in hen's renal tubules following application of the epileptic drug, diphenylhydanation sodium (Tadros and Abdel Halim, 1990). 
S. galilaeus that subjected to the highest concentration of zinc and lead, ghosts of proximal tubules with stil] present pyknotic nuclei were the only demonstrated changes. Similar description was detected by Moussa and AbdelGhaffar (1989) in some renal tubules of rats treated with high doses of "Feldene". It was also detected that hydropic degeneration was so severe to the extent that nothing was seen except parts of the cell boundaries and the compressed dark nuclei.

Kidneys of lead-exposed fish showed that the bases of the renal tubular epithelium were sometimes vaculated. There was also a slight degree of enlargement of intercellular spaces of the tubular epithelium. These renal abnormalities were markedly similar to those produced in the isolated tubules of the English sole incubated in potassium-free buffer (Hickman \& Trump, 1969) and in the brood stock and fathead minnow (Leino et al., 1990) exposed to acid and aluminum. Similar findings were reported by El-Bouhy et al. (1993) in kidneys of fishes exposed to mercury toxicity, where the necrotic epithelium of renal tubules appeared dissociated from their basement membrane.

Degenerations of the renal segments was a prominent feature detected in kidneys of nearly all the exposed fishes. Degenerations were seen near the bases of the distal convoluted tubules and extending upwards, while those demonstrated in the proximal convoluted tubules were starting in the apical regions of the cytoplasm. In some severe cases, at high concentrations of met als, the cytoplasmic degeneration in the epithelial cells was greatly proceeded. In such cells, the nuclei in spite of their obvious pyknosis, still present and persisted Karyolysis. The nephric tubules were nearly looked as if they were ghosts of tubules. These signs of necrosis and inflammations of the kidney tubules due to heavy mat el toxicity are in consistency with those of Baker (1969), who described vacuolatin and disintegration in the apical portion of the renal tubular cells of copper-exposed flounder, Pseudopleuronectes americanus. Vacuolar degeneration of tubular cells and destruction of some of these cells were also observed by Abdel-Latif (1990) in kidneys of Gambusia affinis exposed to copper. According to Wester and Canton (1988), histopathological changes in the kidney tubules of guppy and medaka fishes, 
Al-Zahaby, A.S.;Hemmaid, K.Z.; Gamal, A.M. and Ghonemy, 0.I.

exposed to mercury, were characterized by single cell degeneration and necrosis.

Tubular necrosis was recognized by coagulative necrosis of the tubular epithelium with pyknosis of nuclei and exfoliation into the lumen (Schewie $e t$ al.,

1991). Focal coagulative necrosis of renal epithelium was demonstrated in kidneys of cadmium (El-Bouhy et al., 1993). In such case the renal epithelium was represented by homogeneous eosinophilic cytoplasm with absence of their nuclei. Damage of the kidney units appeared also in the cadmium-exposed fish, Fundulus heteroclitus (Gardner and Yevich, 1970). The damage appeared limited to some proximal tubules which exhibited pink staining granular casts with nuclear debris. Others showed various stages of degenerations.

Renal necrosis was also proved to be induced in the kidney of rat by mercury intoxication (Cuppage et al., 1972 and Nada et al., 1981). Such necrosis was characterized by loss of nuclei and coagulative changes in the cytoplasm. The necrosis was also associated with focal dilation of the convoluted tubules.

The haemopoietic tissue was also necrotic and had pyknotic nuclei in lead groups, or infiltrated with clumps of cells in copper groups or restricted and very much reduced in volume and greatly occupied with clumps of cells and blood corpuscles in zinc group. The haemopoetic tissue was also necrotized and very much reduced in copper-exposed flounders (Baker, 1969). El-Bouhy et al., (1993) reported that, the interstitial tissue in the kidney of fishes exposed to cadmium toxicity was depleted of haemopoietic elements and focal haemorrhage was detected among renal tubules. Hyperplastic haemopoietic interstitial tissues with large polygonal basophilic cells were demonstrated in the guppy and medaka fishes following exposure to mercury (Wester and Canton, 1988). Conversely, Adel-Latif (1990) found that the haemopoitic tissue of Gambusia affinis larvae exposed to copper was increased pronouncedly around the glomeruli and uriniferous tubules. 
Conversely, Wobeser (1975) and El-Bouhy et al. (1993) found that, glomeruli of fish subjected to high levels of met al toxicity especially mercury and cadmium, respectively, had contracted and atrophied glomeruli, so the Bowman's spaces were widely dilated. At the same time, glomeruli appeared shrunken in kidneys of trouts from the wost Salim lakes (Galat et al., 1985). Similar findings were also reported by Miettimen ef al. (1970) in pike and rainbow trout. Also, Kumar and Sirvastiva (1980) observed glomerular shrinkage in Channa punctalus after 10 days in an $8 \% \mathrm{Na} \mathrm{Cl}$ solution.

The present attained findings may lead to the suggestion that factories should be prevented from pouring their effluents in xivers and their tributaries. This is because such category is one of the most important aspects of pollution to the fresh water environment and drastic hazardous effects were proved, by results of the present study, to be produced in internal organs of fishes living in such polluted waters.

\section{Acknowledgement}

The authors are greatly indebted to Prof.Dr.Sabry S. El-Serafy, Professor of Zoology and Head of Zoology Department,Faculty of Science,Zagazig University (Benha Branch).

\section{REFERENCES}

Ibrahim, A.I., Sleem,S.H.; Bahgat,F.G. and Ali, A.S. (1997): Effect of certain water pollutants on the biology of the freshwater clam Caelatura (Unio) aegypiaca (Bivalvia). Egypt.J. Aquat.Biol.Fish.,I(1):47-65.

Abd El-Dayem,S.N.(1990): Effect of benzyl alcohol on function and histology of kidney of rats. Egypt.J.Hist.,13(2):239-245.

Abdel-Latif,H.M.(1990): "Eclogical and histochemical studies on Gambusia fish in relation to habitat pollution".M.Sc.thesis, Fac.Sci.,Tanta Univ. 
Adieb,N., El-Sharouni,S. , Abdel Zaher,K.and Labib,H.(1986): Histological study of the liver, pancreas, kidney and suprarenal of the albino rat under the effect of Medroxy-progesterone acetate.Egypt.J. Histol. 9(2):349-355.

Ali,N.H.(1978): "Comparative histological and histochemical studies on the kidney of vertebrates". M.Sc. thesis, Fac.Sci. Ain Shams Univ.

Al-Zahaby,A.S. . El-Assy,Y.S. and Said-Ahmed,G.A.(1985 a): Comparative morphological and histological studies of the kidneys of fresh water teleost Cyprinus carpio and marine teleost Morene labrax. Proc. Zool. Soc.A.R.E.,9:211-222.

Al-Zahaby,A.S. , El-Assy,Y.S. and Said-Ahmed,G.A. (1985 b): Development of the excretory system of the fresh water teleost Cyprinus carpio. Proc. Zool. Soc. A.R.E. , 9:197-210.

Baker, J.T.P.(1969): Histological and electron microscopical observations on copper poisoning in the winter flounder (Pseudopleuranectes americantus). J.Fish. Res. Bd. Canada, 26: 2785-2739.

Beder,M.A.A.(1983): "Anatomical, histological and histochemical studies on the kidneys of one marine fish and some fresh water fishes".M.Sc. thesis, Fac.Sci. Suez Canal Univ.

Bryan,D.W. (1971): The effects of heavy mat els(other than mercury) on marine and estuarine organisms.Proc.Roy.Soc.London,B.177:389-410.

Colville,T.P. ; Richards,R.H. and Dabbie,J.W. (1983): Variations in renal corpusclear morphology with adadptation to sea water in the rainbow trout,Salmo gairdneri Richardson. J.Fish Biol.,23:451-456.

Cuppage, F.E. . Masahiro,C. and Alfred,T. (1972): Cell cycle studies in the regenerating rat nephron following injury with mercuric chloride.Lab. Invest.,26:122. 
El-Bouhy,Z.; Alkelch,A.M. ; Saleh,G. and Ali,A. (1993): Effects of heavy mat els intoxication on some fresh water.Zagaz.J.Pharmacol. Sci.,2(2):7391 .

Fernandez,B.C.(1977): Histopathological study of the kidney of the trout Salmo irideus intoxicated with technical Warfarin.Bol.R.Soc.Esp. Hist.Nat. Sec.Biol., 75:417-426.

Galat, D.L. . Post,G. ; Keefe,T.J. and Bouck,G.R. (1985): Histological changes in the gill,kidney and liver of Lahontan cutthroat trout,Salmo clarki henshawi, living in lakes of different salinity-alkalinity.J.Fish. Biol.,27:533-552.

Gardner,G.R. and Yevich,P.P. (1970): Histological and haematological responses of an estuarine teleost to cadmium. J.Fish.Res.Bd.Canada, 27:2185-2196.

Ghonemy,O.l.(1986): "Some histological and histochemical studies on the kidneys of some vertebrates." M.Sc.thesis, Zagazig Univ.

Gomma,M.N.E. . Badawy,A.E. and Khayraia,N. (1995): Levels of some heavy mat els in different Egyptian fishes from fresh and marine environments.J.Union Arab Biol., 3(A):177-195.

Grandall,C.A. and Goodnight,C.J. (1963): The effect of sublethal concentrations of several toxicants to common guppy, Lebistes eticulates. Trans. Amer.M icrosc.Soc., 82:59-73.

Harris,H.F.(1900): On the rapid conversion of haematoxylin into haematin in staining sections.J.Appl.Microsc.Lab.Meth.,3:777-781. 
Hemelraad,J. . Herwig,H.J., Van Donselaar,E.G. ; Holwerda,D.A. and Zandee,D.I. (1990): Effects of cadmium in freshwater clams.II. UItrastructural changes in the renal system of Anodonta cygena. Arch. Environ. contamin.Toxicol., 19:691-698.

Herdricks,J.D.(1971): " Histological and histochemical changes occurring in the kidneys of coho salmon (Oncorhynchus kisutch) upon transfer to hypertonic salt concentrations."Ph.D.Dissertation,Colorado,U.S.A. Colorado State Univ.

Hickman,C.P. and Trump,B.J.(1969): The kidney. In W.S.,Hoar and D.J. Randall "Fish Physiology" Vol.I Academic Press,Inc,New York,N.Y.and London .p.91-239.

Hwang,P.P.M. and Wu,S.M. (1988): Salinity effects on cytometrical parameters of the kidney in the euryhaline teleost, Oreochromis mossambicus (Peter).J. Fish Biol.,33:89-95.

Khater,M.O.. Nashed,M.M. and Zaki,M.M. (1991): Hepatorenal toxicity of trichloroethy Lene in albino rats.A microscopic study.Egypt.J.Med.Sci.,12(1): 207-213.

Kirubagaran,R. and Joy,K.P.(1988): Toxic effects of three mercurial compounds on survival and histology of the kidney of the catfish, Clarias bactrachus (L.). Ecotoxicol. Environm.Safety, 15:171-179.

Kumar,S. and Srivastava, G.J. (1980): The effect of sodium chloride on kidney and corpuscles of stannius of Channa punctatus. Zool.Beitr.,26:17179.

Leino,R.L. . Mc Cormick,J.M. and Jensen,K.M.(1990): Multiple effects of acid and aluminum on brood stock and progeny of fathead minnows, with emphasis on histopathology.Can.J.Zool.,68:234-244.

Litchfield,J.T. and Wilcoxon,F,(1949): A simplified method of evaluating doseeffect experiments.J.Pharmacol.Exp.Therap.,96:99-113. 
Miettinen, V. . Blankenstein,E. . Rissanen,K. . Tillander,M. . Miettinen, J.K. and Valtonen,M.(1970): Preliminary study on the distribution and effects of two chemical forms of methyl mercury on pike and rainbow trout. Fao Tech.Conf. on marine pollution and its effects on living resources and fishing, Rome,Italy.

Moussa,K.I.M. and Abdel Ghaffar,E.A.R.(1989): Histological and histochemical studies on the effect of "Feldene " on the kidney of male albino rat.Egypt.J. Med.Sci.,10 (2):427-435.

Nada,S. . El-Samanody,F. . Edress,Z. . Moustafa,N. and Abdel-Hafez, M. (1981): Certain enzymatic reactions in rat kidneys with microbiosis induced ischemia and nephrotoxic agent.Egypt.J.Histol.,4(4): 259-267.

Portmann,J.E.(1970): The toxicity of 120 substances to marine organism. Shellfish Information Leaflet,No,19 MAFF, Burnhamon Crouch.

Rashwan,S. . Abd-El Hafez,M. . El Kallawy,S.and Abd-El Mohsen, A. (1988): The effect of certain stress factors on the histology and histochemistry of rat kidney. Egyp.J.Histol.,1/(1):121-129.

Schiewe,M.H. , Weber,D.D. . Myers,M.S. . Jacques,F.J. . Reichert, W.L.. Krone,C.A. Malins, D.C.. McCain,B.B.. Chan,S.L. and Varanasi,V. (1991): Introduction of foci of cellular alteration and other hepatic lesions in English sole (Parophrys vetulus) exposed to an extract of an urban marine Sedement.Cand. J. Fish Aquat.Sci.,48:1750-1760.

Sippel, A. J. A.. Geraci, J. R. and Hodson, P. V. (1983):Histopathological and physiological responses of rainbow trout (Salmo gairdneri $R$.) to sublethal levels of lead. Water Res., 17:1115-1118.

Stevens, R. W. and Bick, K. L. (1975): Kidney responses to salinity in Ictalurus punctatus, Teleostei, Ictluridae. S.East Biol. Bull.22:81. 
Tadross, N. R. and Abdel Halim, M. (1990): Degenerative lesions in some internal organs of diphenyl-hydantain sodium "DPH-Na" medicated mother hens and their developing embryos. Egypt. J. Histol., 13 (2): 403-417.

Tadross, N. R. and Mohamed, V. E. (1990): Histopathological changes of the liver, Kidney and heart in phenacetin medicated pregnant rats and their offspring. Egypt. J. Med. Sci., 11(1):205-215.

Tadross, N. R. and Said, E. and El-Gohary, Z. M. (1985): The role of caffeine administration during pregnancy in inducing histopathological changes in the liver, kidney and myocardium in both mother rats and their offspring .Egypt.J.Histol.,8(2):189- 195.

Vogel,F. S. (1959): The deposition of exogenous copper under experiments conditions with observations on its neurotoxic and nephrotoxic properties in relation to Wilsons disease. J. Exp. Med.,110:801-809.

Wester, P. W.; Canton, J. H. (1988): Histopathological study of Poecilia reticulata (Guppy) after long-term expose to bis (tri-n-butyltim) oxide (TBTO) and di-n-butyltindichlo-ride (DBTC). Aquat. Toxicol., 10:143165.

Wobeser, G. (1975): Prolonged oral administration of methyl mercury chloride to rainbow trout ( Salmo gairdneri) fingerlings. Fish. Res. Board Can., 32:2015-2023. 


\section{LEGEND OF FIGURES PLATE (I)}

ig.1: A section of the kidney of control $S$. galilaeus showing the nephron sigments; the renal corpuscles, the proximal convoluted tubule (P), the distal convoluted tubule (D) and collecting tubule (ct). (X480).

7ig.2: A T. S of kidney from a fish subjected to copper showing hydropic degeneration of the proximal convoluted tubules (P) and periglomerular edema (arrow).

Fig.3: A T. S of kidney from a fish exposed to copper demonstrating shrinkage of the glomerular tuft of capillaries (G) leading to widening of the Bowmans space, hydropic and vaolar degeneration of the convoluted tubules (ct). The haemopoietic tissue is crowded with infilterated cells . (X240).

Fig.4: A T. S of kidney from a fish subjected to the $\mathrm{LC}_{50}$ of copper. Note the reduced volume of the haemopoietic tissues and hypertrophied renal tubules (rt). Epithelial cells of tubulees are hypertrophied and revealing signs of hydropic degeneration. (X480)

Fig.5: A T. S of kidney from a fish subjected to the highest concentration of copper. Degenerative areas are seen at the bases of epithelial cells of distal and collecting tubules while the proximal ones look like ghosts of tubules, Haemopoietic tissue is altered (X240).

\section{PLATE (II)}

Histopathology in sections from kidneys of fish exposed to sublethal concentrations of zinc (X480). 
Fig.6: A T. S of kidney from a fish, S. galilaeus, exposed to zinc. Note the proximal (P), distal (D) convoluted tubules and the haemopoietic tissue (hp) revealing a rather normal appearance.

Fig.7: A T. S of kidney from a fish exposed to zinc showing glomerulus with enlarged Bowmanns space (Bs) and hydropic degeneration in some renal tubules. Note the macula densa (md) of the distal convoluted tubules.

Fig.8: A T. S of kidney from a fish subjected to the $\mathrm{LC}_{50}$ of zinc showing hydropic degeneration of the proximal convoluted tubules $(\mathrm{P})$ and peritubular degeneration of the distal tubules (D). Nuclei of the altered cells are pyknotc karyorrhectic.

Fig.9: A T. S of kidney from a fish exposed to the high levels of zinc. Note hydropic degeneration in epithelial cells, amyloid degeneration $(A)$ and vacuolar degeneration of proximal (P) and distal (D) convoluted tubules. Also, pyknotic and karyorrhectic as well as karyolytic nuclei are deteced. Numerous proximal tubules are seen as ghosts of tubules.

\section{PLATE (III)}

Histopathology of kidneys from fish exposed to sublethal concentrations of lead and stained with haematoxylin and eosin (X480).

Fig.10: A T. S of kidney from fish, S. galilaeus, exposed to the low levels of lead showing the proximal $(P)$ and the distal (D) convoluted tubules with slight pathologic alternations. The glomeruli showing obvious swelling with deeply basophilic cells.

Fig.11: A T. S of kidney from fish subjected to lead showing peritubular degeneration (arrow). The nuclei of tubules revealing different stages of pyknosis. 
Fig.12: A T. S of kidney from fish subjected to lead showing cloudy swelling and vacuolar degeneration of the proximal (P) and distal (D) convoulted tubules while their nuclei are clearly pyknotic. The hemopoietic tissue is crowded with necrotic cells.

Fig.13: A T. S of kidney from fish subjected to lead demonstrating cellular and nuclear alternations. Note the deformation of the cells lining the renal tubules ( $r t)$. The nephric tubules look like ghosts of tubules. 

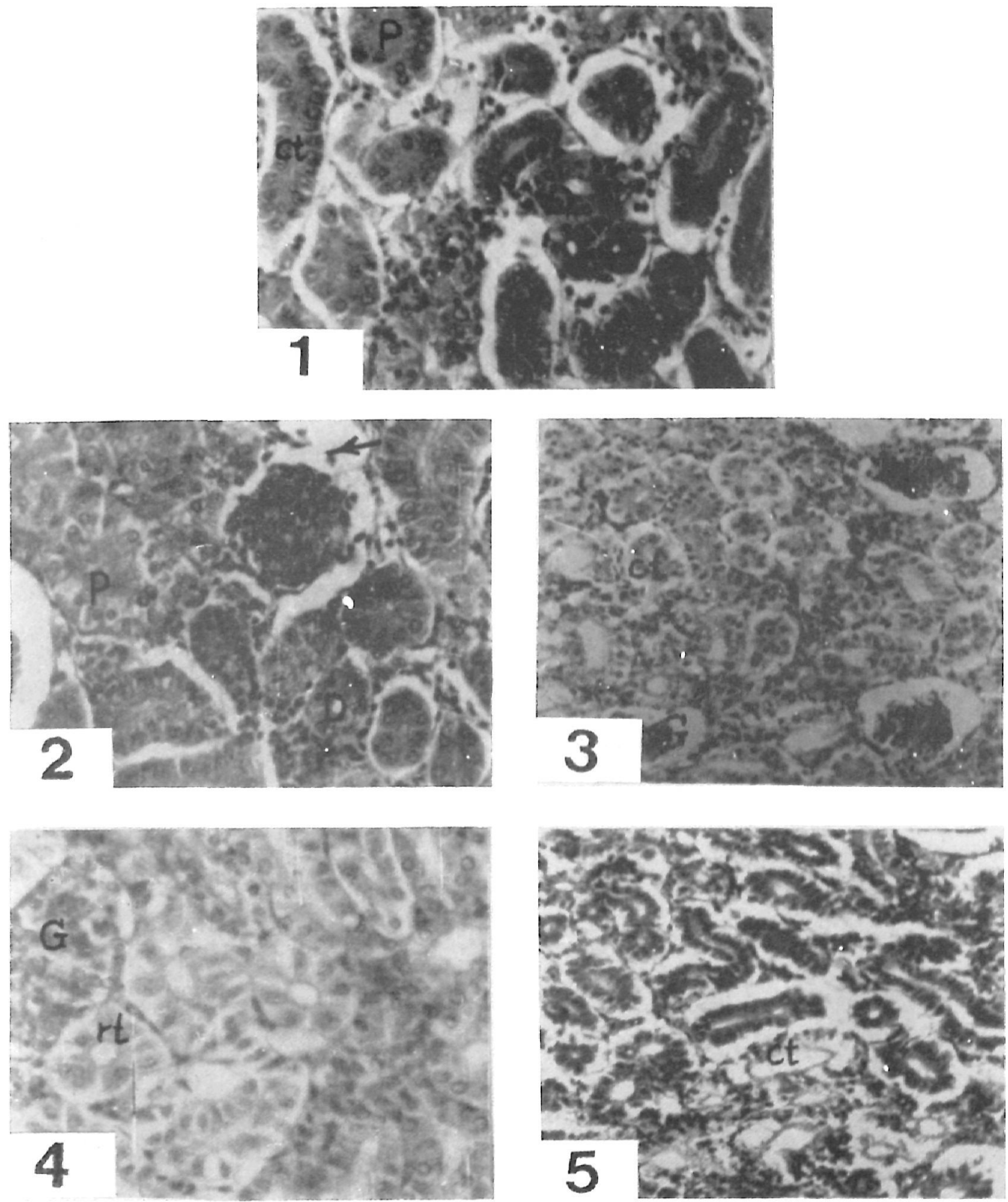

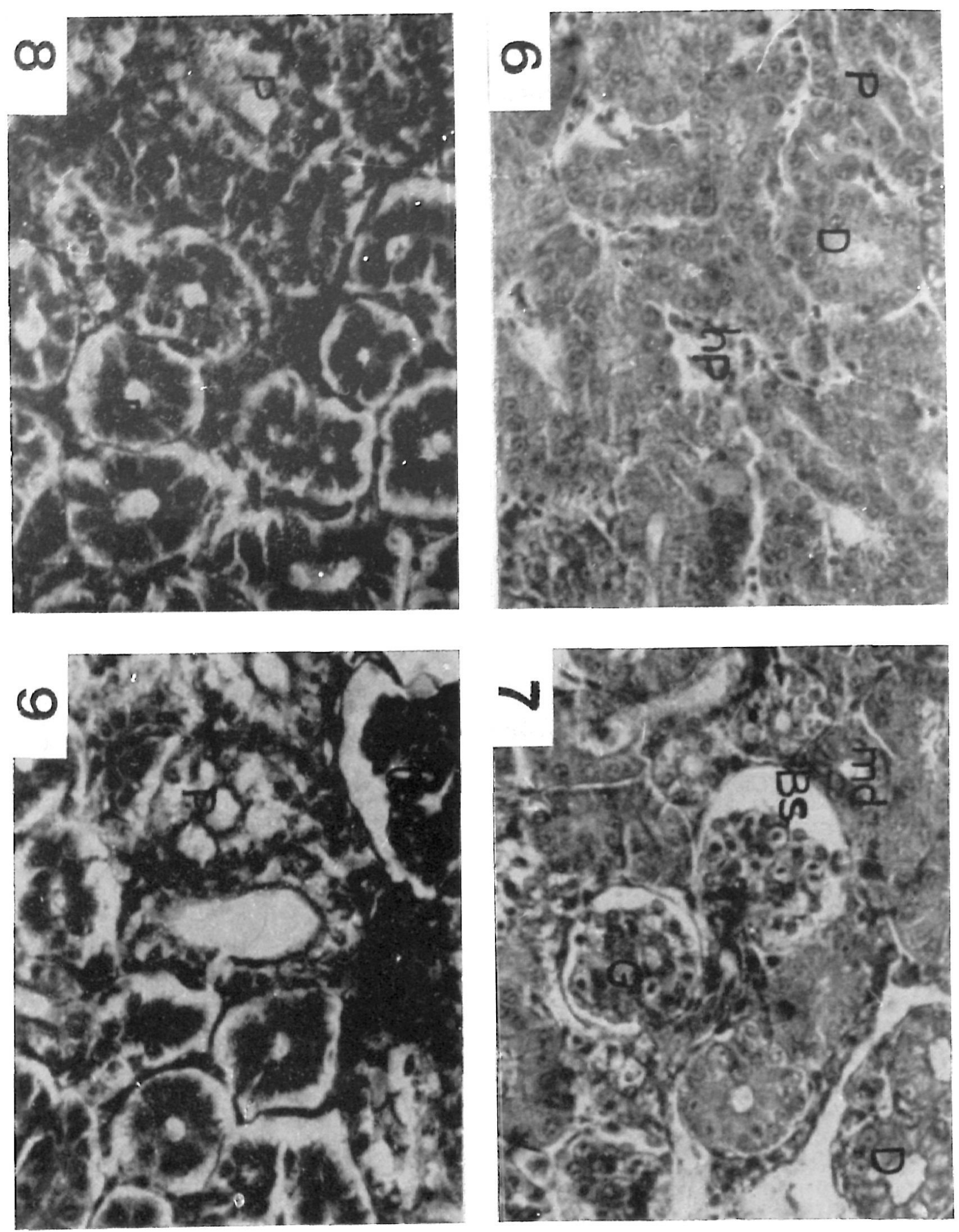

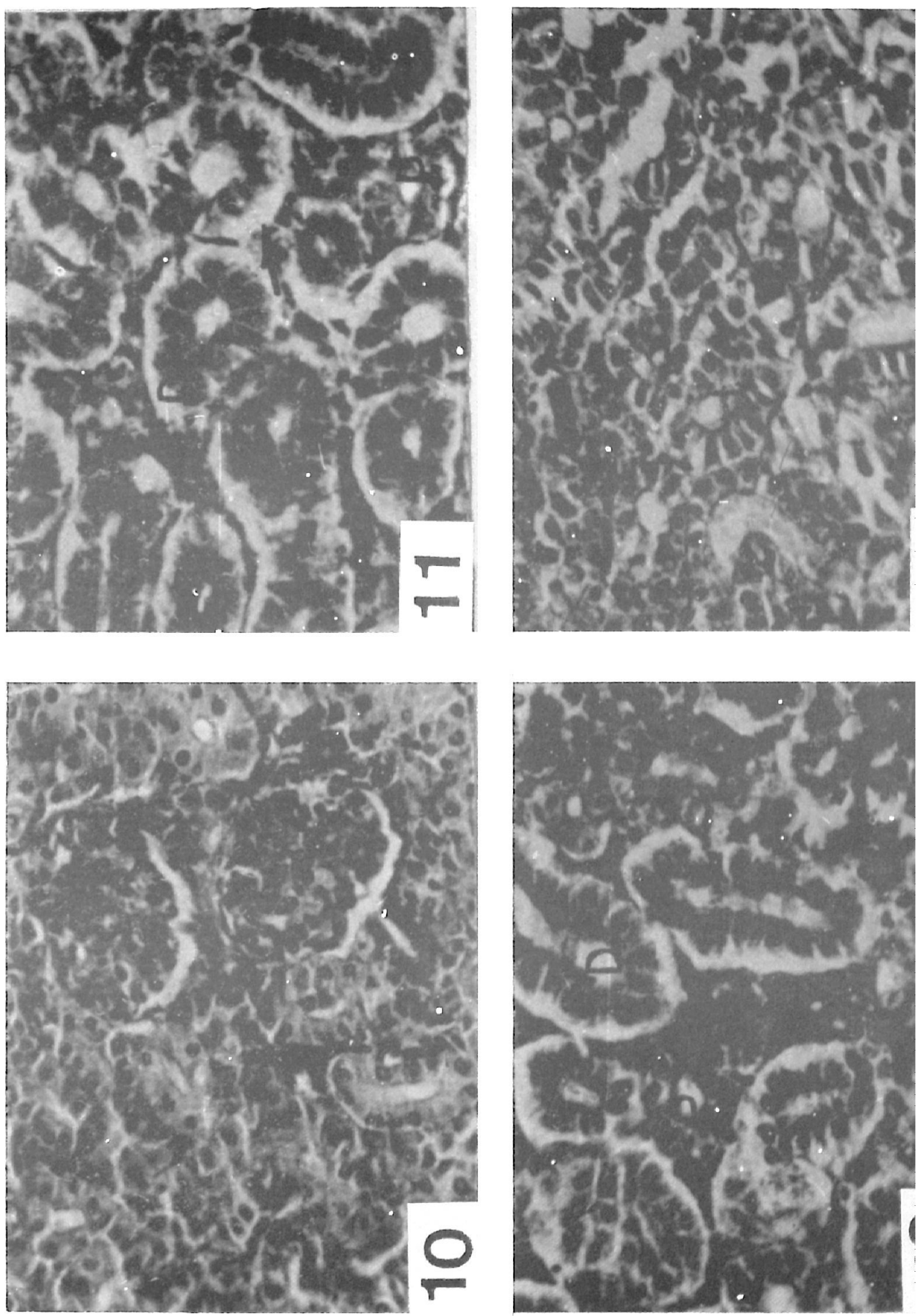


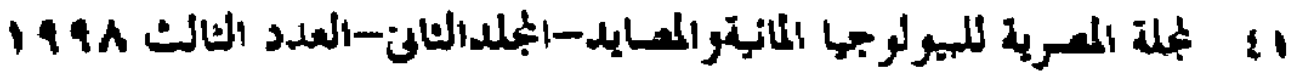

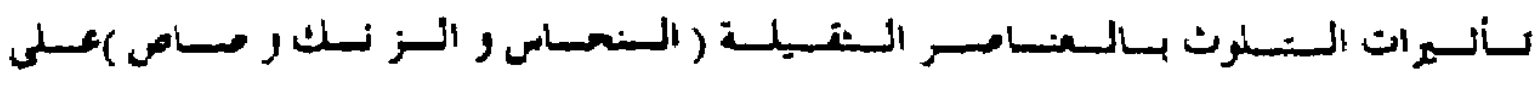

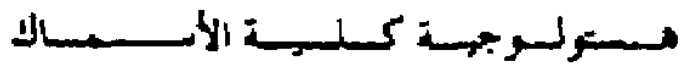

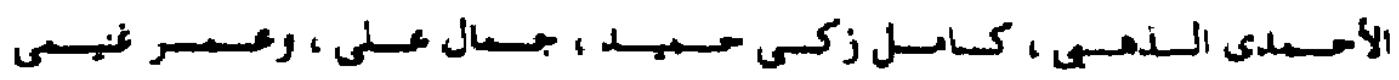

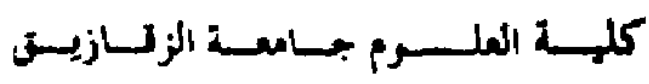

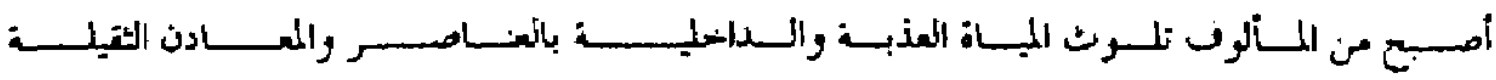

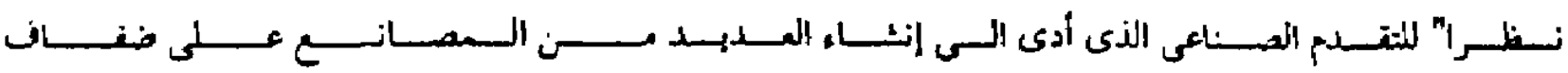

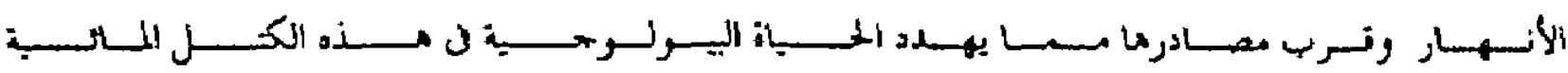
4السمبط

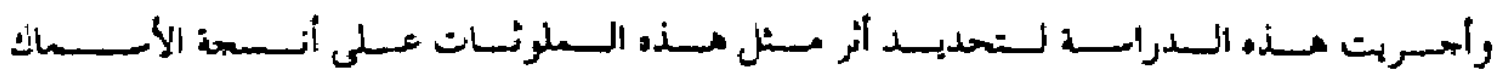

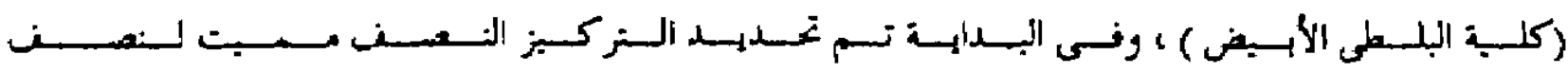

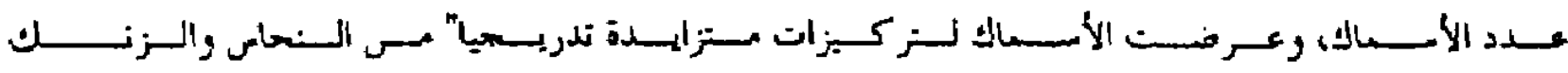

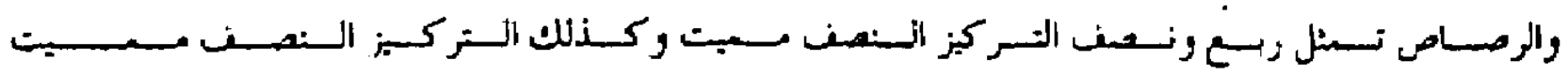

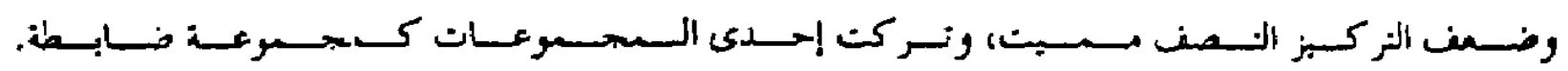

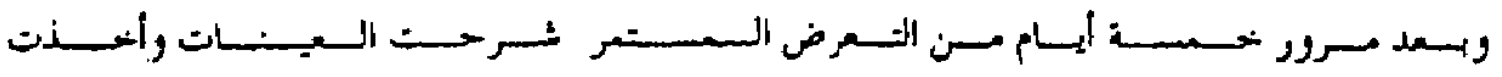

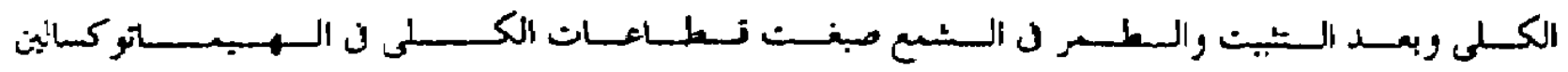

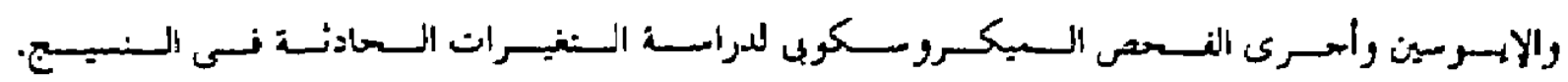

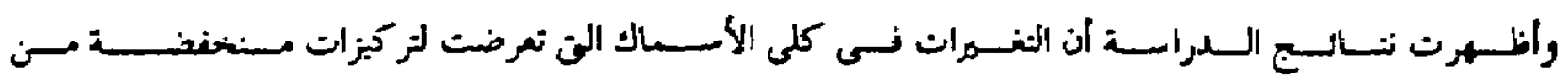

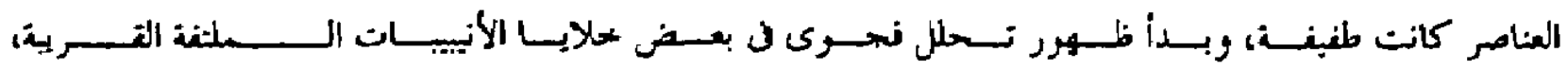

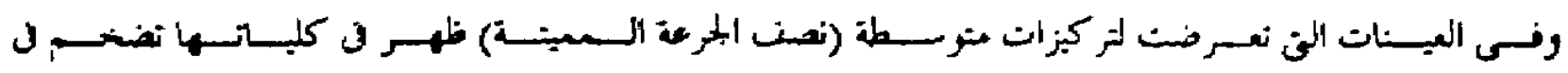

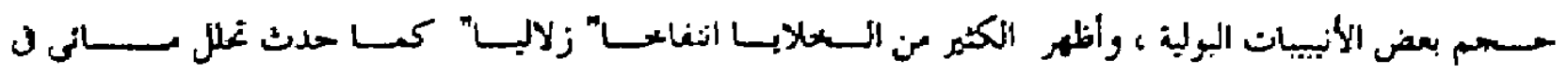

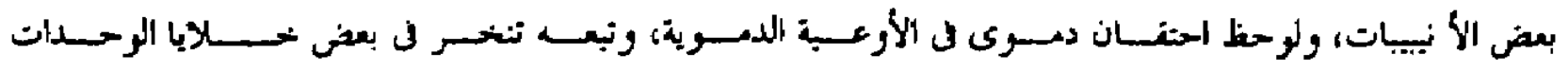

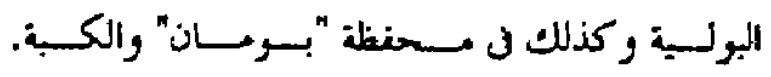




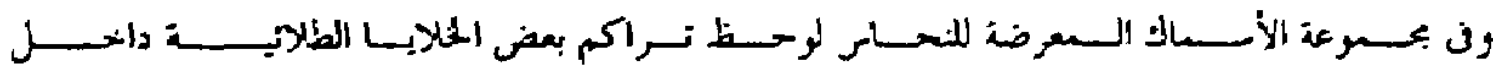

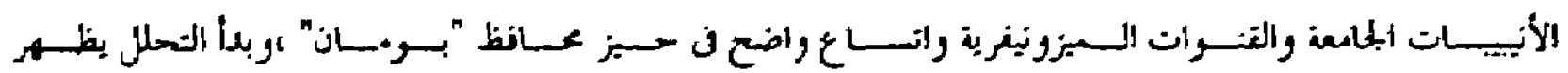

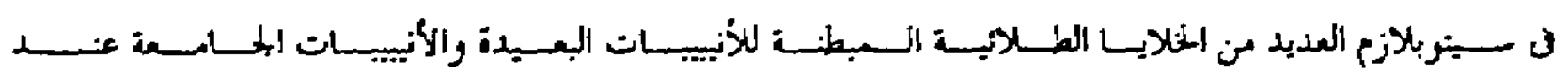
تواعد ثلك إلملايسـا.

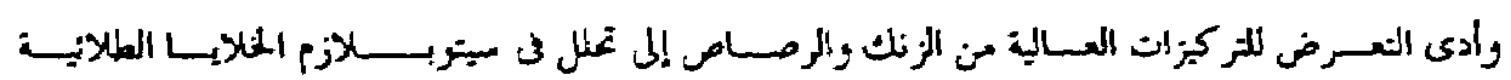

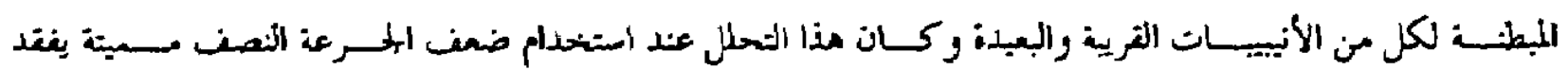

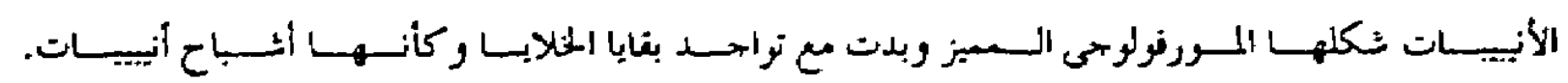

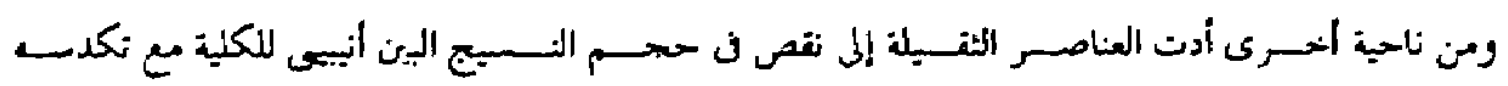

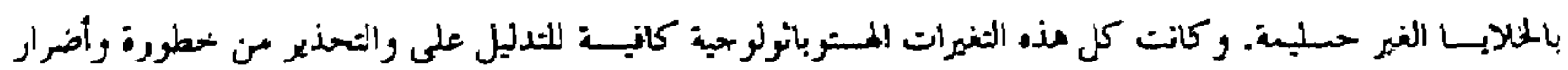

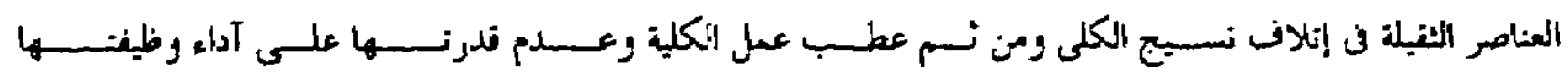
. 